IRA-International Journal of Management \& Social Sciences

ISSN 2455-2267; Vol.05, Issue 01 (2016)

Pg. no. $17-20$

Institute of Research Advances

http://research-advances.org/index.php/RAJMSS

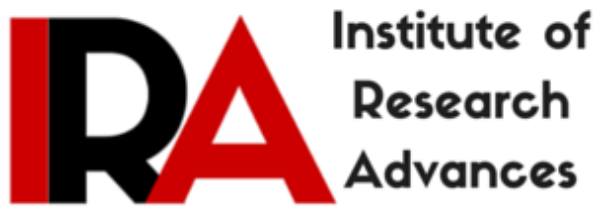

\title{
e-Rickshaws in Delhi - A Green Project : Myth or Reality
}

${ }^{1}$ Dr. Aparna Marwah

Department of Management

Bharati Vidyapeeth University Institute of Management \& Research (BVIMR)

New Delhi, India.

\section{${ }^{2}$ Dr. Daljeet Singh Bawa}

Department of Computer Science

Bharati Vidyapeeth University Institute of Management \& Research (BVIMR)

New Delhi, India.

Type of Review: Peer Reviewed.

DOI: http://dx.doi.org/10.21013/jmss.v5.n1.p3

\section{How to cite this paper:}

Marwah, A., \& Bawa, D. (2016). e-Rickshaws in Delhi - A Green Project : Myth or Reality. IRA-International Journal of Management \& Social Sciences (ISSN 2455-2267), 5(1), 17-20. doi:http://dx.doi.org/10.21013/jmss.v5.n1.p3

(C) Institute of Research Advances

(cc) EY-NC

This work is licensed under a Creative Commons Attribution-Non Commercial 4.0 International License subject to proper citation to the publication source of the work.

Disclaimer: The scholarly papers as reviewed and published by the Institute of Research Advances (IRA) are the views and opinions of their respective authors and are not the views or opinions of the IRA. The IRA disclaims of any harm or loss caused due to the published content to any party. 


\begin{abstract}
e-Rickshaws - a green solution with no petrol, CNG and mobile-oil requirements, electric rickshaws need minimum maintenance and could serve as a solution to last mile commuting problems. Apart from contributing to clean environment; it can also lead to empowerment of people from lower socio-economic backgrounds.

Instead of lessening the burden on the public transportation system, it added to the menace due to lack of proper planning. While efforts have been taken in this regard, but most have been experimental in nature but a concrete solution is yet to arrive. It is high time that legal and safety issues need to be addressed so that it serves its very purpose-sustainable development.
\end{abstract}

Keywords: green, sustainability, empowerment, regularization

\title{
1. Introduction
}

Electric Rickshaws popularly known as e -rickshaws or electric tuk-tuks had posed itself as a convenient and cheap mode of transportation promoting a pollution free and healthy environment. With this intent in the backdrop, the Municipal Corporation of Delhi introduced Electric Rickshaws but did not account for its adverse effects[5].

India being a developing country and New Delhi being the National Capital opens up new avenues for alternative modes of transportation owing to considerable variations in income groups. Initially erickshaws were imported from China but since the export was in large numbers which eventually resulted in problems resulting into gradual shift to Indian manufacturers $[3,4]$. Today, the entire e-rickshaw, along with the body, handle and batteries are manufactured in India, leading to the growth of an entire smallscale industry in the eastern and western parts of Delhi.

E-rickshaws have been gaining popularity since 2010 in Delhi as an alternative to auto-rickshaws and pulled rickshaws (pedi cabs).Battery driven rickshaws today are a complementary transport for the low income group but are widely gaining popularity near thickly populated areas and metro stations [7,9]. It could have been a successful project but now coined as a fuzzy project due to lack of proper planning.

\section{The Plight of e-Rickshaw Project}

A Delhite gets a plethora of transportation facility but the government has been playing a slack role due to improper planning in terms of implementation and consequences.

"Till June 2014, around 137 cases were registered against e-rickshaw drivers for their negligent driving." " There were 36 accidents this year along with 2 deaths". It became a rage after an unfortunate death of a toddler after his mother was struck by an e-rickshaw $[1,2,3]$.

The high court imposed a ban on the plying of e-rickshaws but even today e-rickshaws are running without following any proper certain proposals and guidelines which were drafted by the Central Government. No political party aims at bringing a satisfying solution owing to unrest and vote bank capture issues.

Delhi being a metropolitan city are congested and with a huge variety of alternative modes like autos, pedal driven rickshaws, gram sevaks thus operating it has become nuisance. The road network in Delhi does not have a separate lane for slow moving vehicles and e-rickshaws run at a very slow speed thereby leading to traffic congestion and increasing crush points on the road. 
Consider the situation that e-rickshaws cannot be penalized with a challan for not following traffic rules owing to the fact that it cannot be brought under Motor Vehicles Act and in the initial stage even did not had number plates. The drivers do not require identity cards and license for plying it on roads. As a result, E- rickshaws are not viable in the city. The roads are congested and the battery can last only up to $70 \mathrm{~km}$. E-rickshaws are comparatively lighter in weight and cannot cope with larger weight and there is always a chance of the rickshaw being toppled over if it exceeds the permissible weight. The situation becomes grave owing to the absence of dedicated rickshaw stands and battery recharge stations.

The situation has worsened as we do not have the concept of battery and dedicated parking stations and erickshaws are plying without any fear and this battery operated vehicle needs to be brought under severe scanning.

Initially e-rickshaws were unregulated by any central law in India. However, the Delhi High Court, banned running of e-rickshaws in Delhi on 31 July 2014, over safety concerns raised through a public interest litigation.

\section{Regularization of e-Rickshaws: A Probable Solution}

The solution was sought when Delhi transport minister Nitin Gadkari stated that all e-rickshaws should be regularized through a nominal registration fee of Rs. 100 at MCD and following measures were suggested in this regard:

Identity cards and licences will be issued to the drivers.

$>$ The MCD along with Delhi traffic police will work out a challan system for negligent driving.

$>$ An insurance corpus of Rs 10 lakh has to be made by e-rickshaw associations. This has to cover compensation for any grievous hurt (Rs 25,000) or fatal incident (Rs 1 lakh) caused by an erickshaw.

$>$ These battery-operated vehicles should come under the arms of the Motor Vehicles Act.

$>$ The maximum speed of an e-rickshaw should not be more than $25 \mathrm{~km}$ per hour with a maximum capacity of four passengers.

$>$ The proposal also stated that identity marks and stickers will be issued for e-rickshaws.

In March 2015, the Indian Parliament passed an amendment to the Motor Vehicles (Amendment) Bill, 2015 legalizing E-Rickshaws. By July 2015 Battery Rickshaw are available for travel in many cities, now certified to ply with Registration No. plate by R.T.O. with insurance. [9]

A viable solution must be sought after as banning of e-rickshaws will affect the livelihood of lakhs of people.

\section{Seeing the brighter side: Employability \& Greener}

Another view point is banning of e-rickshaws will hamper the transportation facility for the low income group as they are very convenient, especially within colonies, small lanes or in industrial areas. Many environmentalists believe that if implemented in a planned way, these battery-operated vehicles can be an excellent alternative to petrol/diesel/CNG-driven vehicles, which cause severe pollution. It is also cheap for the owner as well as passengers as they have to pay less transport charges, compared to the charge they pay for auto-rickshaws or hand-pulled rickshaws.[7] They do not make much sound and thus do not add upto noise pollution and thus see electric cycle rickshaws as a sustainable transport system.

If implemented in planned phases, it can also serve as a means of promoting gender equality encouraging women drivers [6]. Bharatiya Mahila Bank Ltd has disbursed around Rs. 20 Lakhs as Mudra Loans to women for purchase and plying of e-Rickshaws. The idea was to encourage women belonging to 
economically weaker sections of the society to contribute to the growth of the country by involving them in economic activities. The Bank is also considering such loans for e-Rickshaws across the country, in places where metro services are available and also took care of the training needs of the women, obtaining of license and area distribution etc of these e-Rickshaw owners. These smart e-rickshaws are equipped with digital gadgets including GPRS and CCTV cameras, keeping women's safety in mind $[10,11]$.

The measures till date are not implemented and require stringent laws to curb the menace and bring order. A change in government policy can lead to a better and sustainable solution.

\section{References}

1. http://www.aljazeera.com/indepth/features/2014/05/regulation-threatens-india-e-rickshaws201451331017908658.html

2. http://archive.indianexpress.com/news/govt-stops-sale-of-erickshaws/1040561/

3. http://archive.thedailystar.net/newDesign/news-details.php?nid=187825

4. http://indianexpress.com/article/cities/delhi/its-cheaper-dealers-import-rickshaw-parts-fromchina-assemble-them-here/

5. http://www.livemint.com/Industry/vGQ4bqUDEnQZtTeSOwRsBP/India-chases-electricmobility-dream.html

6. Mohammad, Anas (Oct 21, 2014). "Meet Tabassum Bano - the first female e-rickshaw driver of Allahabad". I am in DNA of India. Allahabad. .

7. http://www.thehindubusinessline.com/news/states/cheap-rides-low-costs-its-tuktuk-time-intripura/article5690150.ece

8. Delhi Auto Expo: India chases electric mobility dream - Livemint

9. Harding, Simon; Rojesh, Seram (31 August 2014). "Battery Rickshaws in New Delhi and the Regulation Conundrum". Economic and Political Weekly. XLIX (35).

10. http://bmb.co.in/press-release/bharatiya-mahila-bank-distributes-loans-e-rikshaws-women

11. http://www.dnaindia.com/locality/north-west-delhi/now-women-drive-e-rickshaws-delhi-71840 